\title{
ラットの血液，肝臟成分に及ぼす飼料中 大豆リン脂質添加レベルの影響
}

\author{
小畠 義 樹*, 黒田圭 一**, 山口迪夫* \\ * 国立栄盖研究所食品科学部 \\ ** 帝京短期大学家政科
}

\author{
Influences of Dietary Soybean Phospholipids Levels on Hemostatic \\ and Hepatic Components in Young Rats \\ Yoshiki KOBATAKE,* Keiichi KURODA** and Michio YAMAGUCHI* \\ * Division of Food Science, The National Institute of Nutrition, Shinjuku-ku, Tokyo 162 \\ ** Department of Home Economics, Teikyo Junior College, Shibuya-ku, Tokyo 151
}

\begin{abstract}
Nippon Eiyō Shokuryō Gakkaishi (J. Jpn. Soc. Nutr. Food Sci.) 41, 23 28 (1988)
In order to clarify the effects of dietary soybean phospholipid (SP) on hematological parameters, the concentrations of various lipids and proteins, and the activities of enzymes in serum and liver, a $20 \%$ casein diet containing $10 \%$ olive oil (OL) as a control, $2.5 \% \mathrm{SP}+7.5 \%$ OL, $5 \% \mathrm{SP}+5 \% \mathrm{OL}, 7.5$ $\% \mathrm{SP}+2.5 \% \mathrm{OL}$, or $5 \%$ soybean oil $+5 \%$ OL was fed to male Sprague-Dawley rats for 4 weeks. Weight gain and food intake in these dietary groups showed no significant differences, except for a slight suppression of weight gain in the $7.5 \%$ phospholipid group. Erythrocyte and leucocyte counts were similar among all groups, while platelet counts tended to increase with elevation of dietary phospholipid supplement. The concentrations of total lipid, total cholesterol, triglyceride, phospholipid and alpha-tocopherol in serum of rats from the 5\% and $7.5 \%$ phospholipid groups were lower than those in the other groups. However, liver total cholesterol concentrations in all the phospholipid groups were significantly lower than those in the other groups. Activities of serum GOT, GPT and LDH tended to be elevated slightly by the phospholipid supplement. Concentrations of total protein, creatinine and $A / G$ ratios in serum showed no significant differences in all groups. It was suggested from these findings that $5 \%$ or more dietary soybean phospholipid produced a specific physiological effect which might not be attributable to polyunsaturated fatty acids such as linoleate combining with the phospholipid.
\end{abstract}

(Received June 29, 1987)

脂質を多く含む食品中にはかなり多量のリン脂質を含 むものもある。たとえば, 大豆, 落花生, 肝臟, 卵黄な どには $100 \mathrm{~g}$ 中に数 $100 \mathrm{mg}$ 以上のリン脂質が存在し ている。これらの食品を摂取している日常の食生活にお いてはリン脂質もかなり摂取することになるが，今泉ら の調査によると 1 日約 $1.6 \sim 4.4 \mathrm{~g}$ の摂取になるので1), それはど多くはないと考えられる。しかし，最近いわゆ る健康食品としての精製リン脂質の摂取もあると思われ るので, 場合によってはやや多いリン脂質の摂取も考え られる。従来りン脂質の摂取量が血液成分等の変化にど のよらに関係するか検討した報告は多く2) 8)，とくに血

* 厂162 東京都新宿区戸山 1-23-1

** T151 東京都涉谷区本町 6-31-1
清, 肝臓中の脂質, およびリポタンパク質に対する影響 の研究に集中しており，その摄取レベルを变化した条件 での生理作用についての研究は少ない。本研究では大豆 リン脂質を低レベルおよび高レベルで飼料に添加し， ラ ットを約 1 力月飼育したとき, 成長, 血液や肝臓の成分 にどのよらな影響が現れるか検討したので報告する。

\section{実 験 方 法}

\section{1. 実 験動物}

3 週秢の Sprague-Dawley 系の雄ラットを日本クレフ （株）上り睛入し， 1 週間予備飼料 \{カゼイン $20 \%$ ，DLメチオニン $0.3 \%$ ビタミン混合 (AIN-76) $1 \%$, 重酒石 酸コリン $0.2 \%$ ，ミネラル混合 (AIN-76) 3.5\%，七ル 
ロース・パウダー $5 \%$ ，シュクロース $45 \%$ ，オリーブ油 $10 \%, \alpha$-デンプン $15 \%\} に よ り$ 飼育した。飼育室の温 度は $21 \sim 25^{\circ} \mathrm{C}$, 湿度は $50 \%$ 前後に調節し, 明暗は 12

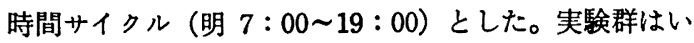
ずれも 1 群 $5 \sim 6$ 匹とし，1匹ずつアパートメント式飼 育ヶージに入れた。飼料と水は自由撖取とした。

\section{2. 実験飼料}

実験飼料は予備飼料中の $10 \%$ オリーブ油の区分を試 験油脂（test lipid）としてオリーブ油または大豆りン脂 質とオリーブ油の混合物などの各種試験脂質に置き替光 ることにより調製した。すなわち，1）10\%オリーブ 油，2） $7.5 \%$ 大豆りン脂質 $+2.5 \%$ オリーブ油， 3) $5 \%$ 大豆りン脂質 $+5 \%$ オリーブ油，4） $2.5 \%$ 大豆り ン脂質 $+7.5 \%$ オリーブ油，5）5\% 大豆油+5\% オリ ーブ油のそれぞれを試験油脂とし， 5 種類の実験飼料を 調製した。リン脂質を飼料と混合するときにはそれをあ らかじめオリーブ油とよく混合した後, 飼料と混合した が，原則として毎日新たに調製した。ラットの実験群は 5 群とし，それぞれの実験飼料を 4 週間投与した。

\section{3. 試菜, 飼料材料および試験脂犋}

実験に用いた試薬はいずれも特級品であった。カゼイ ン， $\alpha$-デンプン，セルロース・パウダーはオリェンタル 酵母工業(株)製; オリーブ油は和光純薬(株) 製; 大豆り ン脂質は豊年製油(株)製であった（Table 1)。

\section{4. 的物処理法}

ラットは 4 週間の実験期間の最終日の早朝 7 時から 7 時間絶食し，ネンブタール麻酔下で心臓から採血するこ とにより屠殺し，ただちに肝臟等の臓器を摘出，秤量し た。肝贜は $0.9 \%$ 食塩水を門脈から圧入することによ り, 十分脱血した。血液は約 1 時間水水中に静置後, $3,500 \mathrm{rpm}, 15$ 分の条件で遠心分離を行い, 血清を分離 した。

\section{5. 測定項目および測定法}

実験飼料投与期間の体重增加量, 飼料摄取量を測定す るとともに，血清および肝臓の成分を測定した。

赤血球，白血球の数およびへモグロビン濃度の測定は 実験飼料投与最終日の前日尾静脈から採血して, 自動血 球計数装置（Toa 社製，CC-108）により測定した。ま た，血小板数はその時同時に全血血小板計数装置（エル マ光学社，PC-601）を用いて測定した。へマトクリット 值は同様に尾静脈から毛細管にとった血液を専用遠心機 で処理し，測定した99。

血清総コレステロール（ステロザイム 545, 富士レビ オ(株)), HDL-コレステロール (HDL-ステロザイム, 富士レビオ(株)), 中性脂肪 (クリンテック TG-S, 1 ヤトロン(株))、リン脂質, $\beta$-リポタンパク質, 遊離脂 肪酸（いずれも和光キット）の測定はいずれる酵素法の キットによって行った。総脂質はスルホホスホバニリン 法10)， A/G 比は BCG 法年), 総タンパクはピューレッ

Table 1. Composition of phospholipids and main fatty acids in soybean oil, olive oil and soybean phospholipid concentrate.

\begin{tabular}{lccc}
\hline & Oilve oil & $\begin{array}{c}\text { Soybean } \\
\text { oil }\end{array}$ & $\begin{array}{c}\text { Soybean phospholipid } \\
\text { concentrate }\end{array}$ \\
\hline $\begin{array}{l}\text { Phospholipid content } \\
(P \times 25) \text {, \% in concentrate }\end{array}$ & & 78.4 \\
\hline & & & (\% in phospholipid) \\
Phosphatidyl-choline & & 33.0 \\
Phosphatidyl-ethanolamine & & & 12.2 \\
Phosphatidyl-inositol+phosphatidyl-serine & & & 34.2 \\
Lyso-phosphatidyl-choline & & & 6.7 \\
Lyso-phosphatidyl-ethanolamine & & 9.9 \\
& & & \\
$14: 0$ & tr.** fatty acid) & 0.1 \\
$16: 0$ & 11.6 & 10.8 & 23.1 \\
$18: 0$ & 2.9 & 3.1 & tr..$^{* *}$ \\
$18: 1$ & 77.0 & 21.1 & 7.6 \\
$18: 2$ & 6.6 & 55.8 & 58.5 \\
$18: 3$ & 0.8 & 8.6 & 7.3 \\
\hline \hline
\end{tabular}

* nd., non-detected. ** tr., trace. 
ト法10), クレアチニンはヤッフェ法によった10)。また， GOT, GPT, LDH はいずれも NADH の減少速度を測 定する方法11), choline esterase はブチリルチオコリン 基質法 ${ }^{12}$ によって測定した。血清および肝缄のリン脂質 はクロロホルムーメタノール混夜（2:1, 以下 C-M 混

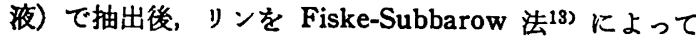
测定算出した。血清 $\alpha$-トュフェロールは五十嵐らの方 法14)による内部標準 2, 2, 5, 7, 8-pentamethyl-hydroxychromanを用いて測定した。血清および肝臓の過酸化 脂質は大川らの方法(5)によった。肝葴総コレステロール は肝臓を C-M 混液で抽出後, ジギトニン沈濒16)を酸発 色法 ${ }^{17} に よ り$ 測定した。

実験データの統計処理は Student's T-test によって 行った。

\section{実験結果および考察}

本実験では大豆リン脂質を通常の $20 \%$ カゼインを含 む基礎飼料へ 3 段階の濃度で添加し，30日間にわたって 投与を続けた後の体重増加量や血液性状，血清脂質等に およぼす影響を以下のように検討した。

\section{1. 体严增加量および飼料掫取是（Table 2)}

4 週間飼料投与後の体重增加量は各群間で統計的に有 意差は見られなかったが， $7.5 \%$ 大豆りン脂質添加群 （群 2）の体重増加量はその他の群に比べやや低かった。 また，飼料摂取量もこの群で低い傾向が見られた。この 結果は大豆りン脂質を $5 \%$ 程度まで飼料に添加しても ットの成長等にはほとんど影響が見られないとしても, $7.5 \%$ 程度の多量の添加においてはなんらかの悪影響が ある可能性のあることが示唆される。

2. 血液性状等 (Table 3)

赤血球数は対照群（群 1 ）に比べ，その他の群でいず れも高まる傾向を示した。とくに $7.5 \%$ 添加群と大豆油 添加群で高くなる傾向をみたが，この原因は明らかでな い。白血球数も対照群に比べ，他の群で増加傾向が見ら れた。血小板数はばらつきが大きいため，有意差は得ら れなかったが，大豆リン脂質を $7.5 \%$ 添加した群が最も 高値を示し，対照群の約 2 倍の数値を示した。 $5 \%$ 大豆 リン脂質添加群でも対照群の約 1.4 倍の高值を示した。 しかし，2.5\% リン脂質添加群ではむしろその数は低下 傾向を示した。これらの結果から，高リン脂質飼料摂取 では一般に血球数が高まる傾向があり，とくに血小板で

Table 2. Weight gain and food intake of rats fed the experimental diets for 4 weeks.

\begin{tabular}{|c|c|c|c|}
\hline \multirow{2}{*}{\multicolumn{2}{|c|}{ Test lipid }} & Weight gain & Food intake \\
\hline & & \multicolumn{2}{|c|}{ (g/4 weeks) } \\
\hline 1) & $10 \%$ olive oil & $197 \pm 8^{*}$ & $491 \pm 13$ \\
\hline 2) & $7.5 \%$ soybean phosholipid $+2.5 \%$ olive oil & $166 \pm 22$ & $480 \pm 23$ \\
\hline 3) & $5 \%$ soybean phospholipid $+5 \%$ olive oil & $188 \pm 12$ & $485 \pm 19$ \\
\hline 4) & $2.5 \%$ soybean phospholipid $+7.5 \%$ olive oil & $204 \pm 19$ & $514 \pm 36$ \\
\hline 5) & $5 \%$ soybean oil $+5 \%$ olive oil & $188 \pm 7$ & $513 \pm 14$ \\
\hline
\end{tabular}

* Mean $\pm \operatorname{SEM}(n=5)$.

Table 3. Hematological data of rats fed the epxerimental diets for 4 weeks.

\begin{tabular}{|c|c|c|c|c|c|}
\hline Test lipid & 1) $10 \%$ olive oil & $\begin{array}{l}\text { 2) } 7.5 \% \text { S-PL1) } \\
2.5 \% \text { olive } \\
\text { oil }\end{array}$ & $\begin{array}{l}\text { 3) } 5 \% \text { S-PL } 5 \% \\
\text { olive oil }\end{array}$ & $\begin{array}{l}\text { 4) } 2.5 \% \text { S-PL } \\
7.5 \% \text { olive } \\
\text { oil }\end{array}$ & $\begin{array}{l}\text { 5) } 5 \% \text { soybean } \\
\text { oil } 5 \% \text { olive } \\
\text { oil }\end{array}$ \\
\hline $\begin{array}{l}\text { Red blood cell } \\
\text { counts }\left(\times 10^{1} / \mathrm{mm}^{3}\right)\end{array}$ & $\left.765 \pm 29^{2}\right)$ & $897 \pm 50^{\mathrm{a} b}$ & $813 \pm 35^{\mathrm{ab}}$ & $842 \pm 31^{\mathrm{ab}}$ & $866 \pm 16^{b}$ \\
\hline $\begin{array}{l}\text { White blood cell counts } \\
\left(\times 10^{2} / \mathrm{mm}^{3}\right)\end{array}$ & $162 \pm 11^{a}$ & $175 \pm 21^{a b}$ & $187 \pm 22^{\mathrm{ab}}$ & $196 \pm 6^{b}$ & $214 \pm 24^{\mathrm{ab}}$ \\
\hline $\begin{array}{l}\text { Platelet counts } \\
\qquad\left(\times 10^{4} / \mathrm{mm}^{3}\right)\end{array}$ & $97 \pm 7$ a & $238 \pm 75^{a}$ & $148 \pm 69 a b$ & $55 \pm 7^{b}$ & $87 \pm 12^{a b}$ \\
\hline $\begin{array}{l}\text { Hemoglobin conentration } \\
(\mathrm{mg} / 100 \mathrm{ml})\end{array}$ & $13.8 \pm 0.6^{a}$ & $15.6 \pm 0.8^{\mathrm{ab}}$ & $15.8 \pm 0.5^{\mathrm{ab}}$ & $15.8 \pm 0.4^{b}$ & $15.2 \pm 0.5^{\mathrm{ab}}$ \\
\hline Hematocrit $(\%)$ & $54.7 \pm 1.7^{\mathrm{a}}$ & $60.6 \pm 2.5^{\mathrm{ab}}$ & $57.5 \pm 2.5^{\mathrm{ab}}$ & $60.2 \pm 2.0 \mathrm{ab}$ & $59.9 \pm 0.6^{b}$ \\
\hline
\end{tabular}

1) S-PL = soybean phospholipid. 2) Mean \pm SEM $(n=5)$. Means in the same horisontal line not sharing a common superscript letter are significantly different $(p<0.05)$. 
その傾向が強いのではないかと考えられた。Galli ら はリン脂質を負荷した場合，血小板それ自身の脂質成分 の変化が起こることを見ているが，血小板数の変化につ いては認めていない。この点についてはさらに検討を要 するものと考えられる。血液へモグロビン濃度は対照に 比べリン脂質と大豆油群で高い傾向が見られ，またへマ クリット值もそれと似た傾向が見られた。

\section{3. 各種血清脂睤濃度 (Table 4)}

総コレステロール值はいずれも対照群に比べその他の 群は全体に低值を示したが，とくに5\%大豆油群と $5 \%$ リン脂質群では差が見られなかった。またリン脂質添加 量増加による影響も認められなかった。総コレステロー ルに対する HDL-コレステロールの割合はリン脂質添加 群と 5\%大豆油群でやや高い傾向を示したが，有意差は 見られなかった。これらの結果は大豆りン脂質を摂取す ると血清コレステロール濃度が低下傾向を示す可能性の あることを示唆していたが，大豆油添加群でもリン脂質 添加群と似た効果を示していることから，それらに含ま れる多価不飽和脂肪酸と関係していることも考えられ る。しかし, 肝蔵の総コレステロール濃度はリン脂質を $2.5 \%$ 以上添加したとき, いずれも対照群や大豆油群よ
り著しく低值を示していた。この関係を $5 \%$ 大豆油群と 5\% リン脂質群について比較しても，明らかに 5\% リン 脂質群で低值を示すことから，肝臓総コレステロール灌 度に対して，リン脂質はそれに含まれる多価不飽和脂肪 酸の効果でなく，リン脂質の構造に関係する作用と考え られる。

血清総脂質濃度は対照群に比べ $7.5 \%$ リン脂質添加群 で強い低下が見られた。これと同じ傾向は血清りン脂 質, トリグリセリドの濃度でも見られ，対照群の $1 / 2$ ま で低下した。しかし，大豆油添加群でも強い低下傾向を 示し,これに対応する $5 \%$ リン脂質群でも血清総脂質, リ ン脂質濃度は同様に低下していた。このことから，共通 成分としての多価不飽和脂肪酸の作用は否定できない。 一方，5\% リン脂質群と $5 \%$ 大豆油群の血清トリグリセ リド濃度の比較ではリン脂質群で低下が見られないの で, リン脂質が $5 \%$ 程度まで飼料に存在する条件ではそ れに含まれる多価不飽和脂肪酸の作用はあらわれにくい ものと考えられる。血清遊離脂肪酸濃度は各群間に差は 見られなかった。血清と肝臓の過酸化脂質濃度は大豆り ン脂質添加に応じて高まる傾向が見られ，血清 $\alpha$-tocopherol 濃度はそれと逆の傾向が見られた。しかしこ

Table 4. Concentrations of various lipids in serum and liver of rats fed the experimental diets for 4 weeks.

\begin{tabular}{|c|c|c|c|c|c|}
\hline Test lipid & 1) $10 \%$ olive oil & $\begin{array}{l}\text { 2) } 7.5 \% \text { S-PL1) } \\
+2.5 \% \text { olive } \\
\text { oil }\end{array}$ & $\begin{array}{l}\text { 3) } 5 \% \text { S-PL } \\
+5 \% \text { olive } \\
\text { oil }\end{array}$ & $\begin{array}{l}\text { 4) } 2.5 \% \text { S-PL } \\
+7.5 \% \text { olive } \\
\text { oil }\end{array}$ & $\begin{array}{l}5) 5 \% \text { soybean } \\
\text { oil }+5 \% \\
\text { olive oli }\end{array}$ \\
\hline $\begin{array}{l}\text { Total lipid concentration } \\
(\mathrm{mg} / 100 \mathrm{ml})\end{array}$ & $710 \pm 35^{2) a c}$ & $386 \pm 15^{b}$ & $452 \pm 29 b$ & $539 \pm 78 \mathrm{c}$ & $401 \pm 22^{b}$ \\
\hline $\begin{array}{l}\text { Serum total cholesterol } \\
(\mathrm{mg} / 100 \mathrm{ml})\end{array}$ & $111.6 \pm 6.7 \mathrm{a}$ & $80.2 \pm 5.9^{b}$ & $81.8 \pm 6.1^{\mathrm{b}}$ & $88.3 \pm 3.2^{b}$ & $85.3 \pm 7.5^{b}$ \\
\hline $\begin{array}{l}\text { Serum HDL-cholestrol } \\
(\mathrm{mg} / 100 \mathrm{ml})\end{array}$ & $75.7 \pm 8.7^{a}$ & $62.3 \pm 3.6^{\mathrm{a}}$ & $64.3 \pm 5.0^{\mathrm{a}}$ & $64.6 \pm 3.2^{a}$ & $64.1 \pm 7.0^{\mathrm{a}}$ \\
\hline $\begin{array}{l}(\mathrm{HDL}-\mathrm{chol} / \mathrm{T}-\mathrm{chol}) \\
\times 100(\%)\end{array}$ & $67.4 \pm 5.4^{\mathrm{a}}$ & $78.1 \pm 1.7^{\mathrm{a}}$ & $78.7 \pm 1.4^{\mathrm{a}}$ & $72.7 \pm 2.3^{\mathrm{a}}$ & $77.5 \pm 2.9^{\mathrm{a}}$ \\
\hline $\begin{array}{l}\text { Serum triglyceride } \\
\quad(\mathrm{mg} / 100 \mathrm{ml})\end{array}$ & $187 \pm 6^{\mathrm{a}}$ & $87 \pm 20^{b}$ & $140 \pm 25^{a b}$ & $171 \pm 59 a \mathrm{~b}$ & $87 \pm 9 b$ \\
\hline $\begin{array}{l}\text { Serum phospholipid } \\
\quad(\mathrm{mg} / 100 \mathrm{ml})\end{array}$ & $207 \pm 11^{\mathrm{ac}}$ & $149 \pm 6^{b}$ & $103 \pm 8^{b}$ & $173 \pm 11^{c}$ & $148 \pm 10^{b}$ \\
\hline $\begin{array}{l}\text { Serum non-esterified fatty } \\
\text { acid }(\mathrm{mEq} / l)\end{array}$ & $0.55 \pm 0.08 \mathrm{a}$ & $0.47 \pm 0.03^{a}$ & $0.44 \pm 0.05^{\mathrm{a}}$ & $0.43 \pm 0.07 \mathrm{a}$ & $0.48 \pm 0.01^{a}$ \\
\hline $\begin{array}{l}\text { Serum lipid peroxide } \\
\text { (nmol. } \mathrm{MDA} / 100 \mathrm{ml})\end{array}$ & $6.75 \pm 0.78^{\mathrm{ab}}$ & $7.51 \pm 0.96^{\mathrm{a}}$ & $7.38 \pm 0.72^{\mathrm{a}}$ & $6.73 \pm 0.60^{a}$ & $5.04 \pm 0.28^{b}$ \\
\hline Serum $\alpha$-tocopherol $(\mathrm{mg} / \mathrm{ml})$ & $6.30 \pm 0.33^{a}$ & $4.41 \pm 0.35^{b}$ & $4.93 \pm 0.30^{b}$ & $6.18 \pm 0.45^{\mathrm{a}}$ & $5.19 \pm 0.36^{\mathrm{ab}}$ \\
\hline $\begin{array}{l}\text { Liver total cholesterol } \\
\quad(\mathrm{mg} / \mathrm{g})\end{array}$ & $3.79 \pm 0.51^{\mathrm{a}}$ & $1.06 \pm 0.16^{b}$ & $0.94 \pm 0.05^{b}$ & $1.45 \pm 0.09 \mathrm{c}$ & $3.50 \pm 0.43^{a}$ \\
\hline Liver phospholipid $(\mathrm{mg} / \mathrm{g})$ & $12.5 \pm 0.9 \mathrm{a}$ & $14.4 \pm 1.6^{\mathrm{ab}}$ & $15.6 \pm 0.5^{b c}$ & $13.5 \pm 1.0 \mathrm{ab}$ & $17.2 \pm 0.6^{c}$ \\
\hline $\begin{array}{l}\text { Liver lipid peroxide } \\
(\mu \mathrm{mol} . \mathrm{MDA} / \mathrm{g})\end{array}$ & $14.1 \pm 1.0^{\mathrm{a}}$ & $18.5 \pm 3.2^{\mathrm{a}}$ & $15.7 \pm 1.1^{\mathrm{a}}$ & $12.7 \pm 1.4^{\mathrm{a}}$ & $16.2 \pm 1.9 \mathrm{a}$ \\
\hline
\end{tabular}

1) $\mathrm{S}-\mathrm{PL}=$ soybean phospholipid. 2) Mean $\pm \operatorname{SEM}(n=5)$. Means in the same horisontal line not sharing a common superscript letter are significantly different $(p<0.05)$. 
Table 5. Activities of various enzymes and protein concentrations in serum of rats fed the experimental diets for 4 weeks.

\begin{tabular}{|c|c|c|c|c|c|}
\hline Test lipid & 1) $10 \%$ olive oil & $\begin{array}{l}2) 7.5 \% \text { S-PL1) } \\
+2.5 \% \text { olive } \\
\text { oil }\end{array}$ & $\begin{array}{l}\text { 3) } 5 \% \text { S-PL } \\
+5 \% \text { olive } \\
\text { oil }\end{array}$ & $\begin{array}{l}\text { 4) } 2.5 \% \text { S-PL } \\
+7.5 \% \text { olive } \\
\text { oil }\end{array}$ & $\begin{array}{l}\text { 5) } 5 \% \text { soybean } \\
\text { oil }+5 \% \\
\text { olive oil }\end{array}$ \\
\hline GOT $(\mathrm{mU} / \mathrm{ml})$ & $95 \pm 12^{2) a}$ & $117 \pm 14^{\mathrm{ab}}$ & $133 \pm 9 b$ & $104 \pm 14^{\mathrm{ab}}$ & $112 \pm 7 \mathrm{ab}$ \\
\hline $\mathrm{GPT}(\mathrm{mU} / \mathrm{ml})$ & $26.6 \pm 1.2^{a}$ & $24.0 \pm 2.0^{\mathrm{ab}}$ & $24.4 \pm 1.1^{\mathrm{b}}$ & $27.2 \pm 3.5^{\mathrm{ab}}$ & $22.2 \pm 1.8^{\mathrm{ab}}$ \\
\hline $\mathrm{LDH}(\mathrm{U} / \mathrm{ml})$ & $430 \pm 16^{a}$ & $622 \pm 78^{\mathrm{ab}}$ & $633 \pm 43^{b}$ & $623 \pm 14^{\mathrm{ab}}$ & $763 \pm 126$ \\
\hline Choline esterase $(\mathrm{mU} / \mathrm{ml})$ & $92.0 \pm 11.5$ & $75.0 \pm 11.4$ & $109.0 \pm 16.7$ & $104.2 \pm 7.5$ & $99.4 \pm 6.3$ \\
\hline Total protein $(\mathrm{g} / 100 \mathrm{ml})$ & $5.80 \pm 0.09$ & $5.82 \pm 0.09$ & $5.94 \pm 0.11$ & $6.08 \pm 0.03$ & $5.92 \pm 0.05$ \\
\hline A/G ratio & $1.00 \pm 0.01$ & $0.97 \pm 0.03$ & $0.98 \pm 0.01$ & $0.95 \pm 0.03$ & $0.98 \pm 0.02$ \\
\hline$\beta$-Lipoprotein $(\mathrm{mg} / 100 \mathrm{ml})$ & $292 \pm 30$ & $225 \pm 22$ & $217 \pm 15$ & $229 \pm 12$ & $197 \pm 14$ \\
\hline $\begin{array}{l}\text { Serum creatinine } \\
(\mathrm{mg} / 100 \mathrm{ml})\end{array}$ & $0.52 \pm 0.02^{a}$ & $0.52 \pm 0.02^{\mathrm{a}}$ & $0.44 \pm 0.02^{\mathrm{b}}$ & $0.52 \pm 0.02^{a}$ & $0.50 \pm 0.00 \mathrm{a}$ \\
\hline
\end{tabular}

1) $\mathrm{S}-\mathrm{PL}=$ soybean phospholipid. 2) Mean \pm SEM $(n=5)$. Means in the same horisontal line not sharing a common superscript letter are singificantly different $(p<0.05)$.

れらの関係において統計的有為差はみられなかった。実 験に使用した油脂の POV はオリーブ油で 1.23 , 大豆 油で 1.75 , 大豆りン脂質で 2.32 であった。この程度の $\mathrm{POV}$ では体内過酸化脂質濃度に油脂酸化物は直接影響 しないと考えられるので，リン脂質摄取がなんらか体内 過酸化脂質に作用を及ぼす可能性があると考えられた。

4. 血清中の酵素活性, その他の成分 (Table 5)

GOT 活性は対照群に比べその他の群ではやや高值の 傾向を示した。また， LDH 活性もこれと似た傾向を示 していた。しかし, GOT, choline esterase 活性は各群 間で差がなかった。このリン脂質投与による肝䁍酵素の 血清中への軽度の漏出は肝蔵に多少負担がかかっている 可能性を示唆している。血清総タンパク質濃度, $A / G$ 比, クレアチニン濃度のいずれも各群間にほとんど差は 見られなかった。また $\beta$ リリポンパク質へのリン脂質 の影響は見られなかった。Russeneu ららによっても VLDL がやや低下傾向にあることを見ているが，リポタ ンパク質に対してはとくに強い影響を与えないと考えら れた。

\section{要 約}

生体内でのリン脂質の利用と生理効果を検討するため に $10 \%$ オリープ油を含む $20 \%$ カゼイン基礎飼料の $10 \%$ オリーブ油区分と大豆から抽出された精製リン脂 質を入れ換えて $2.5 ， 5 ， 7.5 \%$ の割合で大豆リン脂質を 添加した 3 種の飼料群を設けた。また別に $5 \%$ 大豆油を 添加した群と対照の $10 \%$ オリーブ油群を設けた。4週 間飼育後各群間の血清, 肝葴中の成分について比較し た。

これら 5 群間の体重増加量と飼料摄取量には有意差は なかったが， $7.5 \%$ リン脂質群ではそれらはやや抑制さ
れる傾向が見られた。赤血球, 白血球数およびへモグロ ビン濃度は変化がなかった。血小板数はばらつきが大き かったので有意差はなかったが, リン脂質添加量に応じ て増加する傾向が見られた。血清の総脂質, 総コレステ

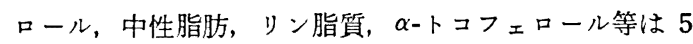
\% 以上のリン脂質添加または大豆油添加群で対照群よ り低值を示した。しかし肝臓中の総コレステロールはり ン脂質添加のみにより著しい低值を示し，大豆油群では 低値を示さなかった。血清中の GOT, GPT, LDH，等 の濃度は各群間に大きな差は見られなかったが，LDH は 5\% リン脂質添加群と大豆油群で上昇が見られた。総 タンパク質, $\mathrm{A} / \mathrm{G}$ 比, クレアチニン濃度等は各群間に 差はなかった。

これらの結果から，大豆リン脂質を飼料中に数\%以上 の多量を添加した場合その脂肪酸の影響も大きいが，リ ン脂質特有の生理効果が現れると考えられた。

大豆リン脂質を提供していただきました豊年製油株式 会社また動物試験用 $\alpha$-tocopherol 粉末を提供していた たきました河合製薬株式会社に深甚の謝意を表します。

\section{文献}

1）今泉勝巳, 村田昌一, 大江政子, 菅野道廣 : 日本 栄盖・食糧学会誌, 37, 185 (1984)

2) Samochowiec, L., Kadlubowsky, D., Rozewicka, L., Kuzna, W. and Szyszka, K. : Atherosclerosis, 23, 319 (1976)

3) Wong, E.K., Nocolosi, J.R., Low, P.A., Herd, J.A. and Hayes, K.C. : Lipids, 15, 428 (1980)

4) Berl, F.U. and Grandy, S.M. : J. Lipid Res., 21, 525 (1980)

5) Rosseneu, M., Declercq, B., Vandamme, D., Vercaemst, R., Soetewey, F., Peeters, H. and Blanton, V. : Atherosclesosis, 32, 141 (1979) 
6) Childs, M.T., Bowlin, J.A. and Ogilvie, J.T. : Atheroscrelosis, 38, 217 (1981)

7) Clark, S.B., Clark, V.E. and Small, D.M. : Am. J. Physiol., 241, G. 422 (1981)

8) Murata, M., Imaizumi, K. and Sugano, M. : J. Nutr., 112, 1805 (1982)

9）寺田秀夫：血液検査の基礎知識（第 2 版）(1982）, 医齿薬出版 (東京)

10）金井 泉, 金井正光 : 臨床検査法提要（第 28 版） (1987)，金原出版（東京）

11) Bergmeyer, H.U. (ed.) : Methods of Enzymatic Analysis, Vol. 2, 574 (1974) Academic Press (New York \& London)

12) Colowick, S.P. and Kaplan, N.O. (eds.) : Methods in Enzymology, Vol. 1, 642 (1955) Academic Press (New York)
13) Fiske, C.H. and Subbarow, Y. : J. Biol. Chem., 66, 375 (1925)

14）五十耑修, 福場博保: 食品中特殊成分分析方法研 究に関する総合研究, 33 (1973), 科学技術庁

15) Ohkawa, H., Ohnishi, N. and Yagi, K. : Anal. Biochem., 95, 351 (1979)

16) Sperry, W.M. and Webb, M. : J. Biol. Chem., 187, 97 (1950)

17) Sobel, C. and Fernandez, A. : Clin. Chem., 12, 739 (1966)

18) Galli, C., Tremoli, E., Giani, E., Maderna, P., Gianfranceschi, G. and Sirtori, C.R. : Lipids, 20, 561 (1985)

（1987 年 6 月 29 日受理） 